\title{
アクティブ微振動制御装置を用いた 磁気シールドルームのノイズ低減に関する検討
}

\author{
正貝阿部隆之（竹中工務店）正員山崎慶太（竹中工務店） \\ 非会貝 宮内哲（部政省通信総合研究所）非会貝 藤 巻 則 夫（郵政省通信総合研究所） \\ 正貝 小林宏一郎 (東京雨機大学) \\ Noise Reduction in Magnetically Shielded Room \\ Using by Active Microtremor Isolation System \\ Takayuki Abe, Member (Takenaka Corp.), Keita Yamazaki, Member (Takenaka Corp.), \\ Satoshi Miyauchi, Non Member (Communications Research Laboratory), \\ Norio Fujimaki, Member (Communications Research Laboratory), \\ Koichiro Kobayashi, Member (Tokyo DENKI University)
}

\begin{abstract}
In biomagnetic measurements such as magnetoencephalography and magnetocardiography, very weak magnetic fields have been measured. Magnetic sensitivity can be limited by microtremor of magnetically shielded room (MSR) used for the measurements as well as environmental magnetic noise at low frequencies caused by streetcars (trains), motorcars traffics and elevators. There are two possible mechanisms for a contribution of vibration of the MSR to magnetic noise : movements of the MSR shielding panels change magnetic field inside the MSR and the vibrating SQUD magnetic sensors receive static magnetic field as time-varying magnetic field.

Thus, it is important to investigate the relationship between magnetic noise and vibration of the MSR, and method for eliminating the vibration is desirable. In this paper, we measured the magnetic noise in the MSR using a 148-channel SQUID magnetometers (BTI) when artificial vibrations were applied to the MSR by means of heal impacts and evaluated correlation between the vibration and magnetic noise. Further an active microtremor isolation system (TACMI) was installed as abase of MSR to reduce the microtremor of the MSR. We also measured reduction of vibration and magnetic noise in an MSR actually mounted on TACMI.
\end{abstract}

キーワード：磁気シールドルーム、生体磁気計測、蕠境振動、磁気ノイス、アクティフ微振動制御装置

\section{1. まえがき}

MEG・MCG等のSQUID磁束計を用いた生体磁気計測で は、 $10^{-12} \sim 10^{-13} \mathrm{~T}$ 程度の微弱な磁界を対象とする。そのため、 磁界計測感度は、地磁気中の自動車やエレベータ等の鉄体 の移動 ${ }^{(1)}$-(3) や、電車の送・帰電流に起因する低周波環境

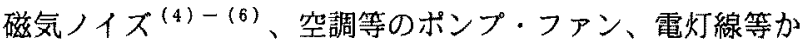
らの磁気ノイズ ${ }^{(7)}$ などに制約される。これらの磁気ノイス は、強磁性体や超電導体で構成された磁気シールドルーム (MSR）によって低減することができるが(8)、磁界計測感 度は、MSR自体の微振動に起因する磁気ノイズ(7)-(9)に 制約・影響される場合がある(8)。

MSRの锁振動に起因する磁気ノイズのメカニスムには、 以下の二つが考えられる。(1) 磁化されたシールドパネルの
微振動がMSR内の磁界を変動させる。(2)MSR内で分布する 残留磁界の中をSQUID磁束計のセンサ自体が振動すること によって、時系列的に変化する磁界変動としてとらえる。特 に(1)のメカニスムの場合、磁界計測感度を向上させるため、 MSRの遮蔽性能を高く設計してシールドパネルの層数、厚 みを增すに従い、影響するパネルの磁化量が增大し、ノイス も大きくなる傾向がある。さらに、SQUID磁束計に差分型 コイルを用いた場合に比べて、マグネットメータ型コイルを 用いた場合、影響が大きくなると考えられる。たたし、キャ ンセレーションが働いていれば、影響仕少なくできる。

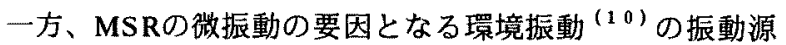
としては、建物外部では地盤の微細な常時微動（数Hz）、 道路・鉄道等の交通機関 $(10 \mathrm{~Hz}$ 前後) があり (11)、建物内 
部では空調機・ダクトなどの設備機械 $(15 \sim 100 \mathrm{~Hz}) 、 人$ の歩行ステップ $(2 \sim 3 \mathrm{~Hz})$ 等があるが、いずれも生体磁気 計測に大きく影響する周波数带である。また、受振体とし てのMSRの振動特性は、これらの伝搬してくる振動源の振 動数とともに、媒体であるMSR自体の固有振動数に依存し、 磁気ノイズもこれらの周波数带で大きく增幅すると考えら れる。

従来からMSRの除振対策は検討されてきた。V.O. Kelhäì は、OTANIEMIのMSRで、周囲の振動をルームに伝えない ために、コンクリート基盤に直接MSRを設置している(12)。

A.Mager等は1980年にベルリンにあるドイツ物理工学研究所 (PTB) に、当時としては世界最高の遮蔽性能（1 Hz以下に おいて遮蔽率が約10,000) を有するMSRを実現したが(13) (14)、MSR内部の活動に起因する振動が遮蔽壁に伝達する ことを防ぐために、遮蔽層を貫通した 4 本の太い黄銅性の 柱で直接コンクリート基礎に固定して、MSR床部を支持し ている(15)。しかしながら、実際に設置されたMSRにおけ る振動に起因する磁気ノイズについては言及されていない。

また、Y.P. Ma等は、13mm厚のアルミニウムと $1.6 \mathrm{~mm}$ 厚 のミューメタルで構成されたパネル 2 層で組み立てられた 内寸 $600 \mathrm{~mm} \times 1,200 \mathrm{~mm} \times 1,700 \mathrm{~mm}$ 、周囲からの振動の絶縁 を考虑した設計の非破買㛟查用MSRを製作した。周囲の床 の振動から絶縁するために、外側層パネルの床とコンクリー トスラブの間には 7 層の防振ゴムが入れられ、MSRの共振 振動を減衰させるために、内側層と外側層の約 $14 \mathrm{~mm} の$ 床部 の層間には、布袋に入れられた約 $1,100 \mathrm{~kg}$ の砂が入れられた。 周冊の実験室床を加振してもMSRの振動に起因する信号は 確認されず、コンクリートスラブからの除振設計に対して 満足した結果を得ている(16)。高橋等は外来振動を防ぐた めに、26面体、重量約10tのMSRを、固有振動 $2.45 \mathrm{~Hz}$ 程度の 4 個のエアーダンパー上に設置した ${ }^{(17)}$ 。しかしながら、

いずれの場合も、MSRの振動と磁気ノイスについての定量 的な知見は明らかにされていない。また、MSRの基礎とし て防振ゴム、エアーダンパー等の3 $\mathrm{Hz}$ 程度の除振装置を用い た場合、その除振効果は除振装置の固有振動数の $\sqrt{2}$ 倍程度 の周波数にあり ${ }^{(18)}$ 、5Hz以下の振動を減衰させることは困 難である。しかも、除振体の固有振動数を低くすると、被 験者がMSRに入った際のMSR自体の振動が減衰するために 時間を要し不快感の要因となり、かつ生体磁気で重要な周 波数带で、振動が増幅するという問題が生じる。

そこで、われわれは室内寸法 $1,300 \mathrm{~mm} \times 1,300 \mathrm{~mm} \times$ $2,100 \mathrm{~mm} 、 44 \mathrm{~mm}$ 厚のボード両側に $1 \mathrm{~mm}$ 厚のパーマロイが 貼られたシールドパネルで組み立てられた簡易型MSR、ア ルミフレームで組んだ自立型のガントレとマグネットメー 夕型SQUID磁束計（ メント社製）を用いた、コンクリート床、壁パネルを加振 させた実験で、以下のことを明らかにした。

コンクリート床を加振した場合のMSRの振動は、ガント レよりパネルの方が変位振幅が大きく、SQUID磁束計に現 れる磁気ノイズは、パネルの水平方向の固有振動数成分で
あった。また、壁パネルを加振した実験では、壁パネルの1 $\mu \mathrm{m}$ の振動によって約1 $\mathrm{pT}$ 磁気ノイスが生したが、MSRが 固定されている床に $10 \mathrm{~Hz}$ 前後で $1 \mu \mathrm{m}$ 程度の環境振動が伝搬 した場合、壁パネルでは $10 \mu \mathrm{m} に$ 増幅するため、磁気ノイス は10pT以上であることが判明した ${ }^{(19)}$ 。また、二次勾配型

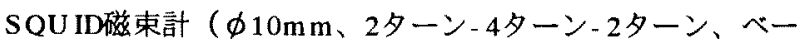
スライン $25 \mathrm{~mm}$ 、セイコーインスツルメント社製）によって 環境振動に起因する磁気ノイズを計測した場合、マグネット メータ型に比べて小さくなることを明らかにした(20)。

しかしながら、本実験の結果はあくまでもプロトタイプ の実験用MSRとSQU ID磁束計で得られた結果であり、汎用 の大型で高性能なMSR ${ }^{(21)(22) 、 カ ゙ ン ト レ と マ ル チ チ ャ ン ~}$ ネルSQUID磁束計 (23)-(25)で構成された生体磁気計測シ ステムでは、振動特性、磁気ノイス特性もおおいに異なると 予測される。さらに、シールドパネルの磁化と振幅から解析 的に磁気ノイズ求める方法も試みられているが、パネルの磁 化の大きさ・方向は、MSRの地磁気に対する方向および組 み立て方法、輸送方法によって大きく異なるため、解析結果 を実湘の傾向、絶対值と近ずけることは困難である ${ }^{(26)}$ 。

以上のように、沉用のマルチチャンネル生体磁気計測シ ステムで用いられている大型で高性能なMSRの振動と磁気 ノイズの複雑な関係を実験的に明らかにし、その除去方法を 検討することは、生体磁気計測の精度を向上させるために重 要である。

そこで、本報告では、まず、MSRの振動と磁気ノイスの 相関を明らかにするために、ヒールインパクト（足踏み）加 振時におけるMSR内磁気ノイズを、148チャンネルSQU ID 磁束計（BTI社製、マグネットメータタイプ）を用いて測定 し、MSRの振動と磁気ノイズとの相関を実験的に評価し、 振動と磁気ノイズの関係を定量的に明らかにするとともに、 磁気ノイスのピークが同じ周波数に存在すると考えられる MSRの固有振動数を求めた。

さらに、MSRの微振動を低減させるためにアクティブ微 振動制御装置（TACMI）をMSRの基礎として操用し、振動・ 磁気ノイズの低減効果を以前のモデル解析 ${ }^{(27)(28)}$ を基に 評価した。TACMIは、定盤上のセンサが振動をキャッチす ると、デジタルコントローラが最適な制御力を計算し、即座 にアクチュエータが逆方向の力を発生させて振動を打ち消す ため、防振ゴム、エアーダンパー等のパッシブ装置単独では 不可能な、地盤振動、歩行ステップなどが要因となる数 $\mathrm{Hz}$ 以下の除振が可能である特改を有している。そのため、 MSR内における被験者の微小な動き等に起因する振動も、 速やかに減衰することが期待できる。

\section{2. 実験方法}

図 1 に実験に使用したMSR(トーキン製AK3夕イプ、バキュー ムシュメルツ社設計）、SQUID磁束計、TACMIの概要と振 動加速度測定点を示す。通常の基礎は鉄骨で構成するが、 TACMIに用いた基礎は磁気ノイズを考慮して、コンクリー 卜（非磁性鉄筋）構造とした。そのため、基礎の厚さ 


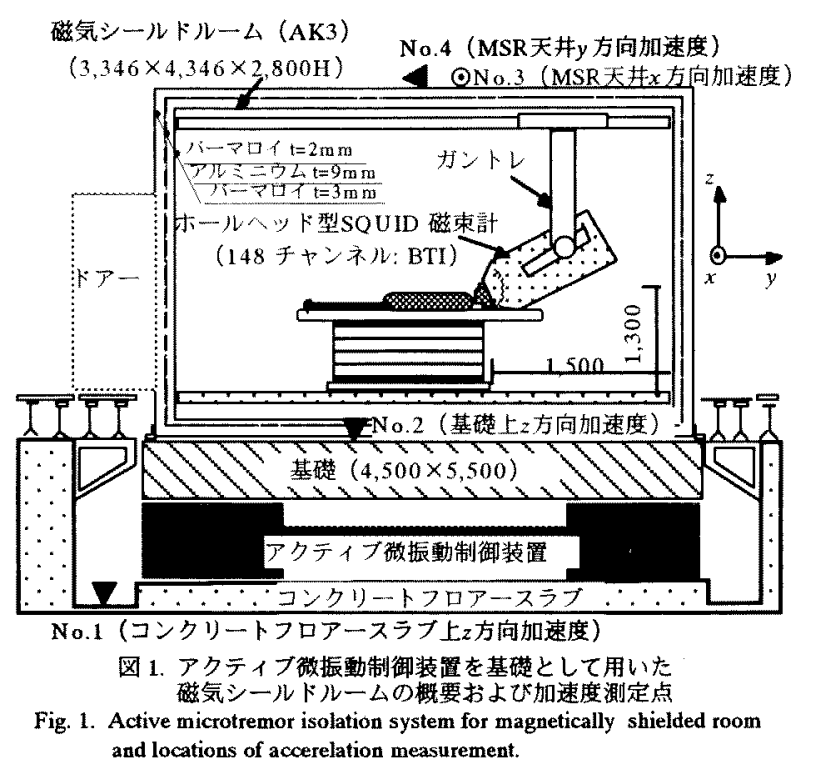

$500 \mathrm{~mm}$ は、有限要素法解析により最も弾性モード（基盤が ゆがむ）の振動数が高く、コスト的にもより安洒の厚さに なるように設計した ${ }^{(29) 。 ~}$

実験に使用したMSRは、解析結果の一般性と再現性を持 たせるため、市販品 (AK3) を用い、外側 $2 \mathrm{~mm}$ 厚、内側 $3 \mathrm{~mm}$ 厚の 2 層のパーマロイと、その間の 1 層の $9 \mathrm{~mm}$ 厚アル ミニウム層で構成され、各周波数の交流磁界に対しての遍 蔽性能は、0.1Hzで $40 \mathrm{~dB} 、 1 \mathrm{~Hz}$ で $60 \mathrm{~dB} 、 10 \mathrm{~Hz}$ で $82 \mathrm{~d} \mathrm{~B}$ 、 $10 \mathrm{kHz}$ の周波数帯では $100 \mathrm{~dB}$ 以上である(21)。また、MSR の長手方向を南北に向けて設置してある。簡易型MSRでは ガントレは自立型であったのに対して、本MSRではガント レは天井パネルに取り付けられたレールから支持されてお り、MSR内の任意の場所での測定が可能になっているが、 SQUID磁束計デュアの重量が天井バネルにかかりデュアは より振動しやすい可能性がある。今回は扉反対側の壁からy 方向に約 $1,500 \mathrm{~mm} 、 x$ 方向はMSRの中央で、高さはホール ヘッド型デュアの頭部中心で約 $1,300 \mathrm{~mm}$ の位置にSQU ID 磁 束計を設置した。148チャンネルSQUID磁束計から 3 チャ ンネルを選定し、 $x$ 方向 $(B x) 、 y$ 方向 $(B y) 、 z$ 方向 $(B z)$ の磁気信号を計測した。たたし、磁気ノイスを取り出すた め、通常のMEG計測の際に行っているノイズキャンセレー ション（環境磁気変動を他のSQUIDにより計測し、信号 SQUIDに重み付けをして引き算する方法）は停止して測定 した。実験に際し磁気ノイズに主として影響を与えるMSR の振動方向を確認する目的でMSRの天井パネル（z方向）、 水平方向 $(\mathrm{x}, \mathrm{y}$ 方向）の振動加速度を測定した。その結果、 同一加振力に対し、3方向の振動加速度は、MSRの弱辺方向 (短辺方向) である $\mathrm{x}$ 方向が最も大きいことが分かった。そ の理由は、MSRの水平方向に関する剛性は、平面形状とし てx方向がy方向より寸法が小さいことから（短辺方向また は弱辺方向）弱くなっており、振動すると考えられるため である。また、天井パネルの上下方向（z方向）については、 コンクリート床に対して振幅が認められずガントレとの相
関が生じないため、磁気ノイズは現れないと推定される。し たがって、MSR内の磁気ノイスとの相関は振動が大きい MSRのx方向に限定して実験を行った。

まず、TACMI無稼働時（除振機能なし）に、基礎（No.2） を 4 段階（強、中、弱、極弱）の強度（レベル）でヒールイ ンパクト加振させ、MSRのx方向振動加速度（No.3）と磁気 信号の相関を評価するとともに、MSRの振動增幅特性を評 価した。また、振動に起因する磁気ノイスの大きさが依存す ると考えられ、磁化されたシールドパネルによって形成され るMSR内残留磁気分布を、SQUID磁束計センサとほぼ同じ 高さの $H=1,200 \mathrm{~mm} 、 500 \mathrm{~mm}$ 間隔で、 $x 、 y 、 z$ 各方向別に、 フラックスゲート型磁力計を用いて測定した。

次に、同じくTACMI無稼働時に、コンクリートフロアー スラプ (No.1) をヒールインパクト加振させ、磁気信号、 加速度の周波数スペクトルを測定し、MSRの固有振動数を 確認するとともに、磁気信号のピーク周波数について検討し、 MSRの微振動に起因する磁気ノイスのメカニスムについて 考察した。さらに、TACMI稼働時に、無稼働時と同しよう にコンクリートフロアースラブ（No.1）をヒールインパク 卜加振させ、TACMI無稼働時の振動加速度、磁気信号と比 較して、加振時における磁気ノイス低減効果を評価した。

最後に、加振なしの磁気ノイススペクトルを、TACMI無 稼働時、稼働時で比較し、通常の状態におけるアクティブ微 振動制御装置の磁気ノイス低減効果を評価した。

\section{3. 実験結果}

<3.1> 磁気シールドルームにおける振動と磁気ノイズの 相関 図 2 に、基礎をヒールインパクト加振した場合（加振 レベル：中）の磁気信号、加速度の時系列変動を示す。 No.3の加速度振幅はNo.2に比べて約2.5倍になっていること

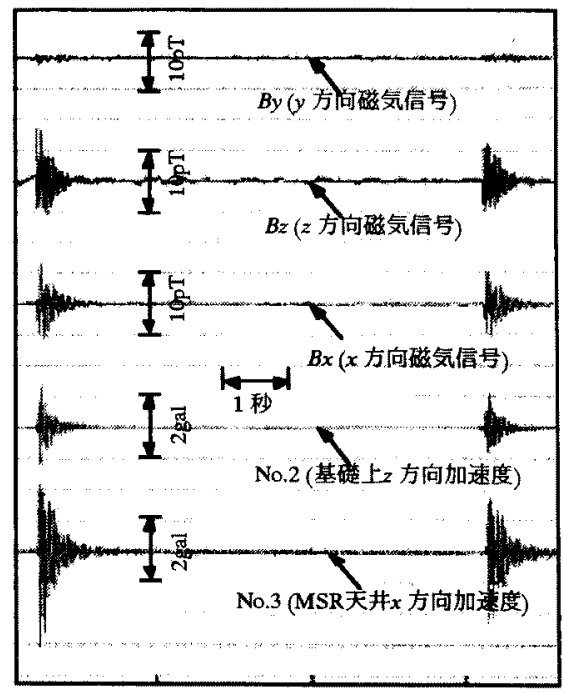

図 2. 磁気信号および振動の時系列波形 (基礎加振、強度中)

Fig. 2. Fluctuations of magnetic signals measured with SQUID magnetometers and accelerations when artificial vibrations were applied by means of heal impacts on table (medium vibration level). 
表 1 MSR天井 $x$ 方向加速度（No.3）と磁気信号との相関係数

Table 1. The correlation coefficients between the accerelation at No.3 and the magnetic signals.

\begin{tabular}{c|c|c|c}
\hline 加桭加速度の强店 & $B x$ & $B y$ & $B_{z}$ \\
\hline 強 & 0.74 & 0.14 & 0.80 \\
\hline 中 & 0.73 & 0.04 & 0.80 \\
\hline 尉 & 0.75 & 0.03 & 0.73 \\
\hline
\end{tabular}

から、MSRの振動增幅率ては約2.5であると考えられる。簡

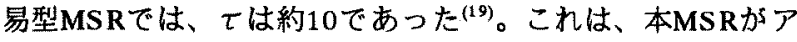
ルミ9mmの板の接合部をチャンネルで締め付けた構造体で あることに対し、簡易型MSRはパネルの組み合せのみでで きているためである。また、磁気信号 $B x 、 B z$ の波形は、 No.2、No.3の加速度の波形と類似している。表 1 に、No.3 加速度と磁気信号 $B x 、 B y 、 B z$ の相関係数 $(\mathrm{CC})$ を示す。 CCの解析にあたり加速度と磁気ノイズの位相差を考虑して、 磁気ノイズ $(16 \mathrm{~Hz})$ の 1 周期内における最大值を相関係数 として用いた。No.3加速度とBx、BzとのCCは、それぞれ $0.73 、 0.80 て ゙$ 高い相関が認められたが、ByとのCCは0.04で あり相関が認められなかつた。

振動測定によりMSRの振動の主な方向はx方向であると認 められたので、磁気ノイスはSQUID磁束計の測定点を通る $x$ 軸に沿った残留磁気 $\left(B x^{\prime} 、 B y^{\prime} 、 B z^{\prime}\right)$ の分布（MSRパネ ルに起因する) から検討した。図 3 の(a)、(b)、(c)に、MSR 内各方向 $B r x 、 B r y 、 B r z$ の残留磁気分布測定結果をそれそ れ示す。図 3 で、Brx、Bry、Brzとも入り口付近の勾配は 大きいが、(a)のBrx、(c)のBrzにはSQUID磁束計のある中 心付近で大きな勾配が存在しているのに対して、(b)のBry には大きな勾配は認められず一様であった。振動の主方向 に沿ったMSR内残留磁気分布で、勾配の大きい方向である $x$ 方向（水平短辺方向）、 $z$ 方向（垂直方向）では、振動と磁 気ノイスには高い相関があり、勾配の小さい方向であるy 方 向（水平長辺方向）には、低い相関がある傾向が認められ、 振動に起因する磁気ノイズの方向は、残留磁気分布にある 程度依存していると考えられる。

図 4 に、No.3の加速度から求めたMSR天井パネルの変位 $\Delta x$ と、磁気信号から求めた磁気ノイス振幅 $\Delta B x 、 \Delta B z$ との 関係を示す。 $\Delta B x 、 \Delta B z$ は $\Delta x$ とほぼ比例して大きくなって おり、MSRの天井パネルの水平変位振幅が約 $1 \mu \mathrm{m}$ であつ た場合、 $x 、 z$ 方向で約 $1.5 \mathrm{pT}$ の磁気ノイスとなることが、 回帰直線から推測することができる。MSRの水平変位振幅 に対する䃍気ノイズの大きさとしては、簡易型MSRを用い た実験で得た、同じく $1 \mu \mathrm{m}$ の微振動によって約1pTの磁気 ノイスが生ずる結果 ${ }^{(19)}$ に比べて、やや大きくなっている。

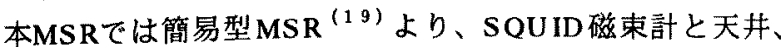
壁のシールドパネルの距離は大きくなっているにもかかわ らず、上記の結果を得た理由としては、パーマロイ $2 \mathrm{~mm}$ 、 $3 \mathrm{~mm}$ の 2 層でMSRが構成され、 $1 \mathrm{~mm} 2$ 層の簡易型MSRよ り、パネルの磁化量が增大したからと考えられる。

図 5 に、コンクリートフロアスラブを加振した場合の磁

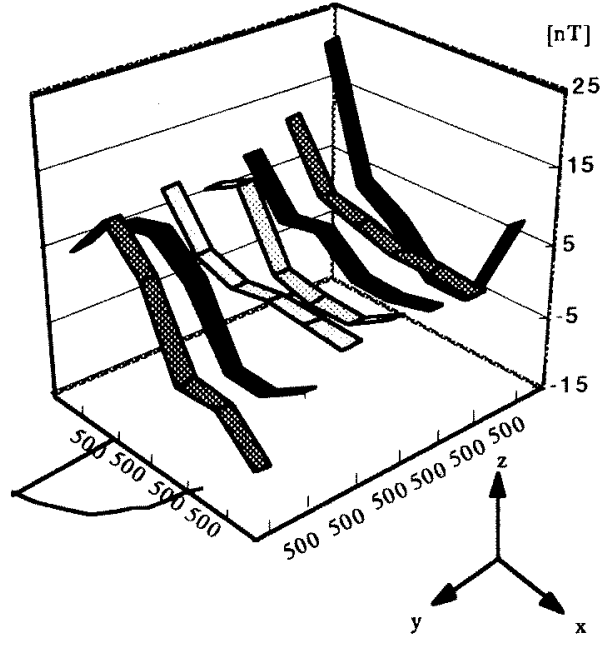

(a) $x$ 方向 $(B r x)$

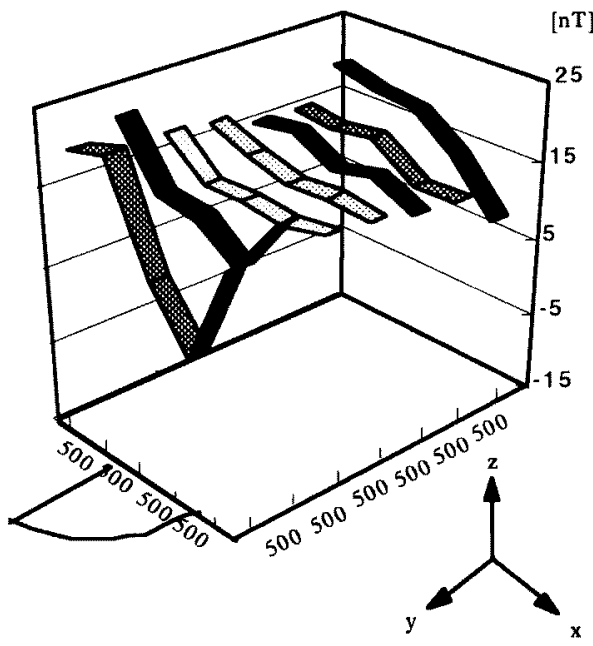

(b) $y$ 方向 (Bry)

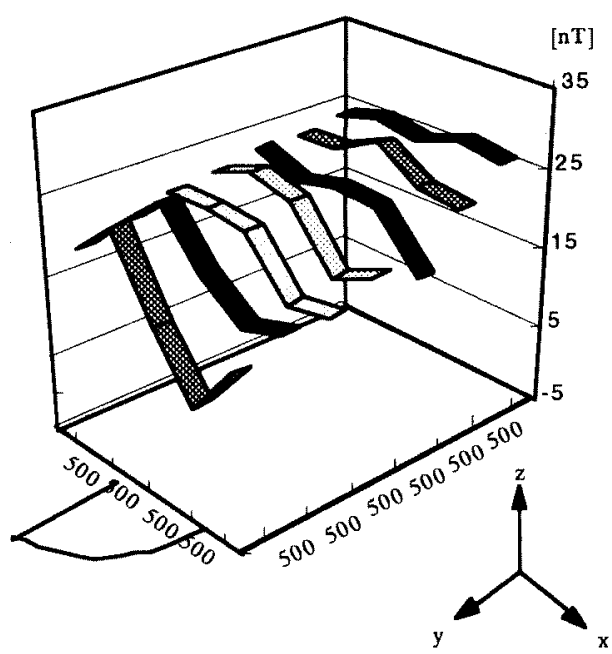

(C) $z$ 方向 $(B r z)$

図 $3 x$ 軸に治ったMSR内残留磁気各方向成分の分布 $(H=1,200)$

Fig.3 Distribution of directional residual magnetic field along $x$-axis $(H=1,200)$. 


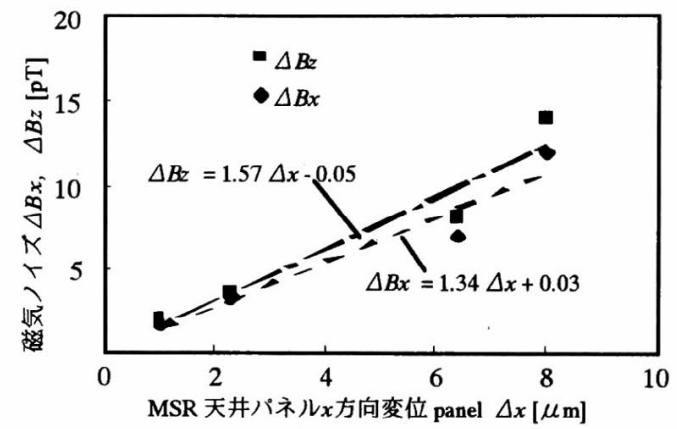

図 4. 磁気ノイズと磁気シールドルーム天井パネル $\mathrm{x}$ 方向変位との関係

Fig. 4. Relationship between magnetic noise and displacement in $x$-direction of the MSR ceiling panel.

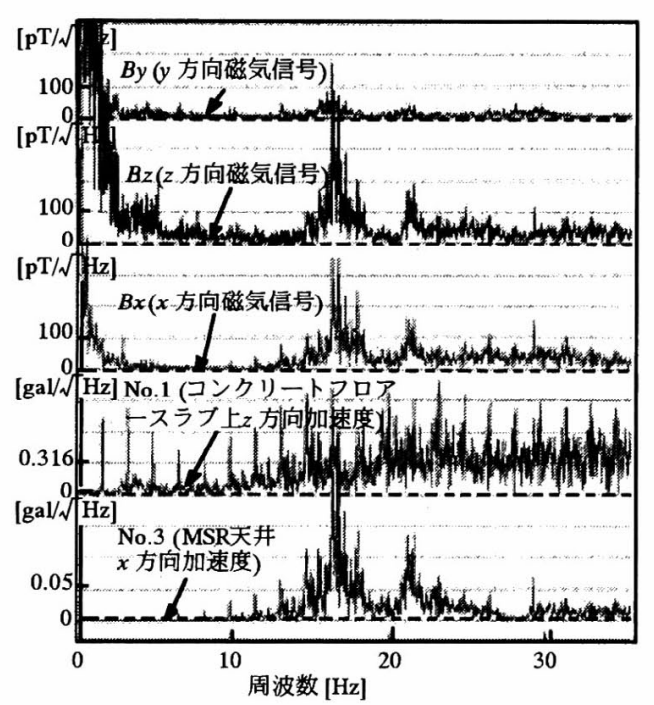

図 5. 磁気信号および振動の周波数スベクトル (コンクリートフロアースラブ加振、TACMI無稼㗢時)

Fig. 5. Spectrum densities of magnetic signals measured withSQUID magnetometers and accelerations when artificial vibrations were applied by means of heal impacts on concrete floor slab. (without TACMI's operation)

気信号、加速度の周波数スペクトルを示す。図 5 で、No.3 加速度には16 Hz、21.5 Hzのピークが認められるのに対し て、No.1加速度には同じピークが存在しないことから、16 Hz、21.5 HzがMSRの固有振動数であると考えられる。別 途測定したSQU ID ガントレの固有振動数は、 $6 \mathrm{~Hz} 、 14 \mathrm{~Hz}$ であった。MSRの振動と相関が高かった $B x 、 B z$ の磁気信号 の主なピーク周波数は、No.3 加速度のピークと一致してお り、6 Hz、14 Hzには認められなかった。これは、基礎に 固定されているMSRの質量に対し、デュアの質量が数十分 の一と小さいため、MSRの振動特性が支配的であることに

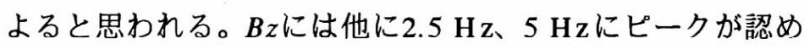
られたが、No.3加速度には同じピーク周波数が存在しなかっ たので、振動でない他の環境磁気ノイズに起因すると考え られる。MSR構造体の剛性と強度を向上させた場合、上で 計測した固有振動数より高くなることが考えられるが ${ }^{16)}$ 、減 衰定数には変化がないため振動増幅率の低隇には寄与でき

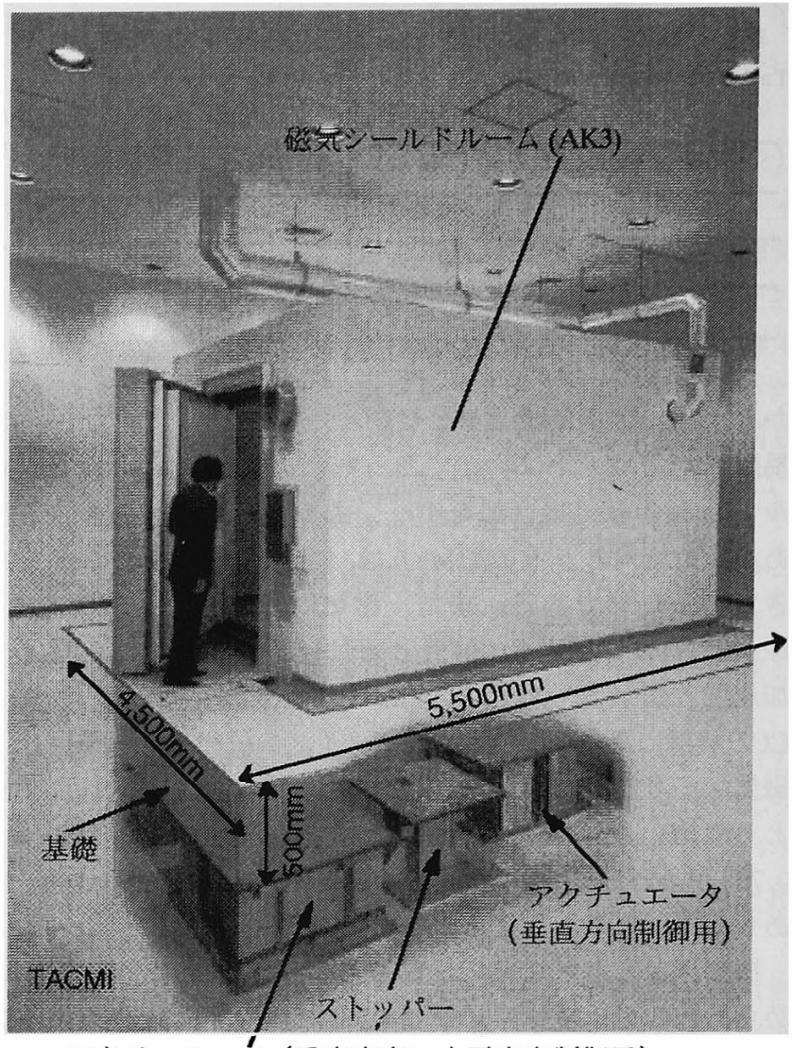

アクチュエータ（垂直方向、水平方向制御用）

図 6. アクティフ微振動制御装置上に設置された 磁気シールドルーム

Fig. 6. Magnetically shielded room mounted on TACMI.

ない。そこで、振動に起因する磁気ノイズを低減させるため には、MSRが設置された床からの振動を遮断することが最 も効果的であると考えられ、TACMIをMSRの基礎として用 いることにした。

<3.2> MSRの基礎としてアクティブ微振動制御装置を用い た場合の評価図6に、郵政省通信総合研究所で実際に設 置したアクティブ微振動制御装置（TACMI）を示す。 TACMIには、約 $500 \mathrm{~mm}$ のコンクリート板（基礎）と約 $10 \mathrm{t}$ のMSRが積載されており（図 1)、基礎を1 Hz以下の低い 振動数までの微振動に対して、6 自由度 $(x, y, z, \theta x, \theta y$, $\theta z)$ の制御を行っている。図6に示すように、TACMIの 制御にはエアーアクチュエータを用いているが、エアーアク チュエータから発生する磁気ノイズについては、パーマロイ 製ボックスを用いて十分な磁気遮蔽対策を行った。

図 7 に、TACMI稼働時のコンクリートフロアスラブ （NO.1）から基礎（NO.2）への伝達関数を示す。さらに、 今回のアクティブ微振動制御装置では、アクティブ制御なし でエアークッションのパッシブ制御のみの場合についても、 同様に伝達関数を測定した。図 7 に示すように、TACMIは、 パッシブ制御のみの場合と比べても、10Hz以下で大きな減 衰特性を有している。

図 8 に、TACMI稼働時における、コンクリートフロアー スラブ (No.1) をヒールインパクト加振させた場合の、加 


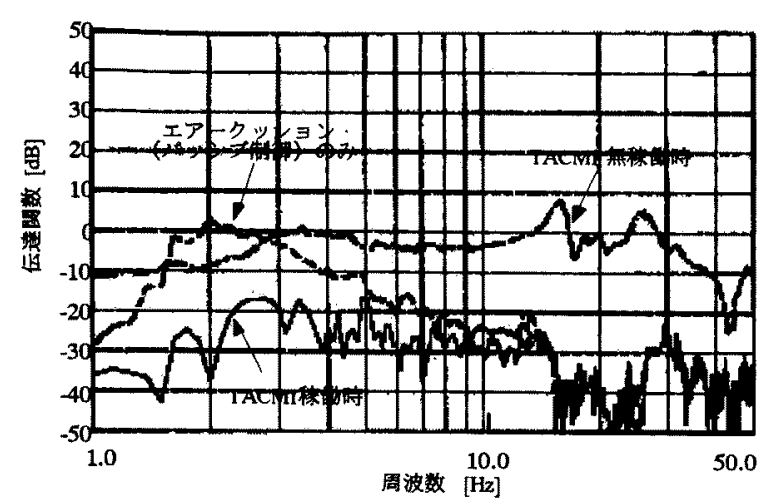

図 7. No.1(コンクリートフロアースラプ)から No.2(基礎)への伝達関数測定結果

Fig. 7. Transfer function between the accerelation at No.1(on floor slab) and No.2(on table).

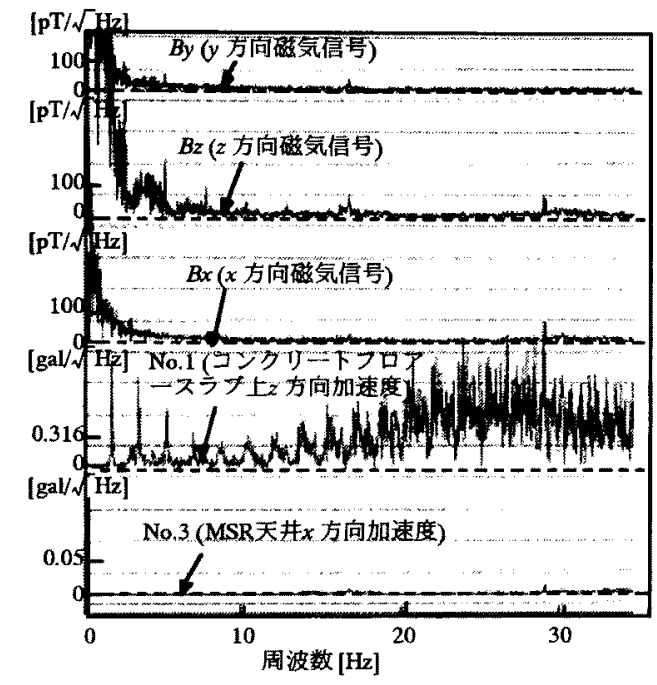

图 8. 磁気信号および振動の周波数スベクトル (コンクリートフロアースラフ加振、TACM稼働時)

Fig. 8. Spectrum densities of magnetic signals measured with SQUID magnetometers and accelerations when artificial vibrations were applied by means of heal impacts on concrete floor slab. (with TACMI's operation ).

速度、磁気信号の周波数スペクトル測定結果を示す。図 8 のBx、Bz、No.3加速度では、図 5 で認められた $16 \mathrm{~Hz}$ 、 $21.5 \mathrm{~Hz}$ のピークが明瞭に低減された。しかしながら、 TACMI稼働時にかかわらず、BzとNo.3加速度には $29.5 \mathrm{~Hz}$ に小さなピークが認められたが、これはコンクリート基礎 定盤のモード実験結果より、弾性モード（基盤がゆがむ） と考えられる(30)。

図9,10に、暗振動でのTACMI無稼働時、稼働時の加速度、 磁気信号の周波数スペクトル測定結果をそれぞれ示す。暗 振動の状態でも、図 9 のTACMI無稼働時では、コンクリー トフロアースラブをヒールインパクト加振させた場合に比 ベて、レベルは下がるが、基礎上 $z$ 方向（No.2）、MSR天井 $x$ 方向（No.3）の加速度とBx、BzにはMSRの $x$ 方向の固有振 動数と考えられる16Hzと、24Hz、29.5Hz（図 5 では表示 感度の違いより小さく見えている)には明瞭なピークが認

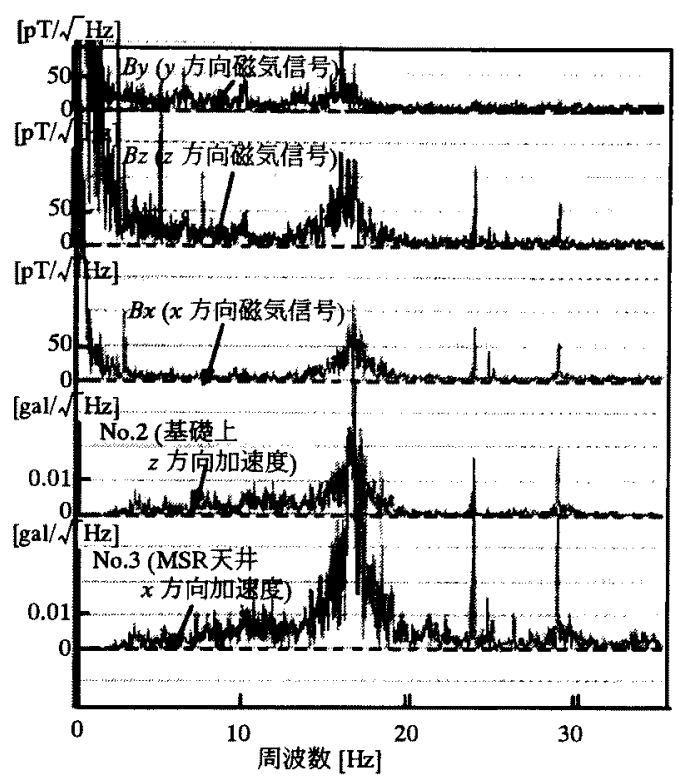

図 9. 磁気信号およひ振動の周波数スペクトル (暗振動、TACMI無稼働時)

Fig. 9. Spectrum densities of magnetic signals measured with SQUID magnetometers and accelerations when no artificial vibrations were applied. (without TACMI's operation ).

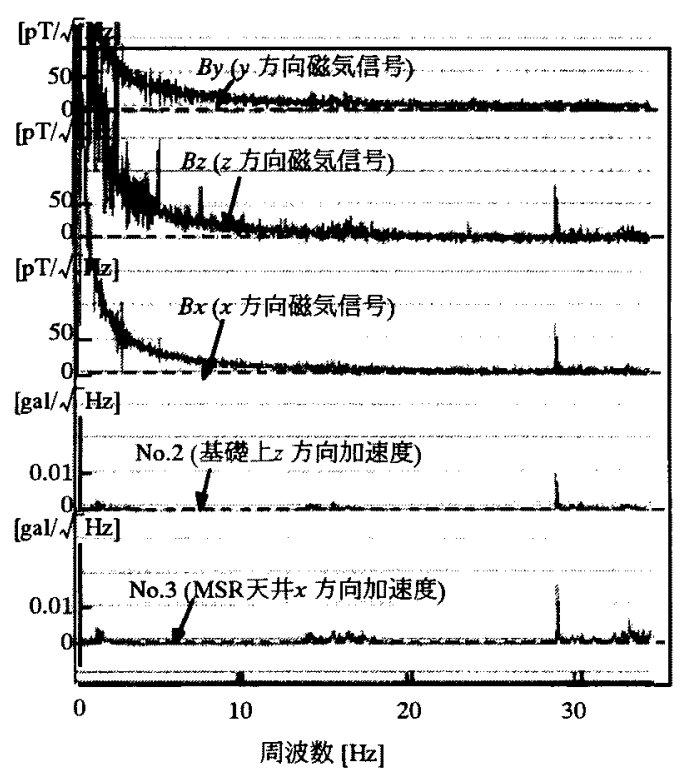

図 10、磁気信号および振動の周波数スペクトル （暗振動、TACMI稼働時）

Fig. 10. Spectrum densities of magnetic signals measured with SQUID magnetometers and accelerations when no artificial vibrations were applied. (with TACMI's operation).

められた。16HzのピークはByにも㸾められる。さらに、 $11 \mathrm{~Hz}$ 付近にもNo.2、No.3とBy、Bzにはビークが認められ る。それに対して、図100TACMI稳働時では、図 9 で認め られた $11 \mathrm{~Hz} 、 16 \mathrm{~Hz} 、 24 \mathrm{~Hz}$ のピークは振動、磁気信号で認 められず、暗振動の状態でも、TACMI振動に起因する磁気 ノイスの低減効果か確認された。TACMIを用いることによっ て、磁界計測感度の向上に有効である。ただし、29.5Hzの 
ピークは、加振の場合と同様に、TACMI稼働時でも振動、 磁気信号で認められた。

\section{4. まとめ}

汎用の生体磁気計測システムで用いられている大型で高 性能、長方形の形状を有する磁気シールドルームの水平方 向（短辺方向）の加速度と、水平方向（短辺方向）、垂直 方向の磁気ノイスにはそれそれ高い相関が認められ、磁気 ノイズ振幅は、シールドバネルの変位振幅にほぼ比例して いた。本MSRの固有振動数は $16 \mathrm{~Hz}$ 、振動增幅率 $て は$ は約 2.5 であり、MSRを含む本生体磁気計測システムでは、天井バ ネルの水平変位振幅が約 $1 \mu \mathrm{m}$ であった場合、 $x 、 z$ 方向で約 $1.5 \mathrm{pT}$ 磁気ノイスとなっていた。一方、磁気ノイズのピー ク周波数には、ガントレの固有振動数は認められなかった。 このことから、本実験の微振動に起因する磁気ノイスは、 主に1で述へた(1)の磁化されたシールドパネルの微振動に 依存すると考えられる。

さらに、 $\mathrm{x}$ 方向に沿ったMSR内残留磁界分布で、勾配の大 きい方向では振動と磁気ノイスには高い相関があり、勾配 の小さい方向では低い相関がある傾向が認められた。振動 に起因する磁気ノイスは、振動の主方向に沿った残留磁気 分布勾配の大きい方向で大きくなると考えられる。

アクティフ微振動制御装置をMSRの基礎として用いるこ とによって、MSRの固有振動数を含む低周波の掓動に起因 する磁気ノイズを低隇できることが、コンクリートフロア スラブを加振した場合、暗振動の場合、それそれの実験で 確認できた。

今後、シールドパネルの磁化を仮定して、シミュレーショ ンにより予め磁気ノイズを予湘する手法をさらに㭘討した W。

\section{(平成 11 年5月 31 日受付，平成 11 年 8 月 2 日再受付)}

\section{文献}

（1）松葉博則・藤巻則夫・宮内哲：「磁性体，電流線の 及ぼす環境磁気雑音」, 日本生体磁気学会論文誌, $10,2,1 \sim 10$ (1997)

（2）山崎慶太・藤原耕二・高橋則雄 - 湯ノ口万友・鎌田 清孝：「磁性体の移動に起因する磁気ノイズ解析」， 電気学会マグネティックス研究会資料, MAG-98-145 (1998)

（3）鎌田清孝·湯ノ口万友・山崎慶太 - 中瀨知哉・藤原 耕二・高橋則雄・：「磁性体の移動に起因する磁気 ノイズの考察」, 日本応用磁気学誌，23，2，1509 〜1912 (1999)

（4）山崎慶太・小谷誠・内川義則：「電車からの低周波 磁気ノイズについての考察 一生体磁気計測用磁気 シールドルームの設計のために一」, 日本応用磁気 学誌, 15, 2, 597〜600 (1991)

（5）山崎慶太・湯ノ口万友・栗城真也 - 内川義則 ·小林 宏一郎・鎌田清孝・中瀬知哉・西本英彦・藤原耕二：
「生体磁気計測のための低周波環境磁気ノイスに関 する検討 一市電に起因する磁気ノイスー」，電気 学会マグネティックス研究会資料，MAG-97-223 (1997)

（6）山崎慶太・湯ノ口万友・鎌田清孝・内川義則：「鹿 児島市における市電に起因する低周波環境磁気ノイ スに関する検討」，日本生体磁気学会論文誌，10， 2, 29 39 (1997)

( 7 ) Vrba J : "SQUID gradiometer in real environments", $\mathrm{H}$. Weinstock (eds) SQUID Sensors, Fundamentals, Fabrication and Applications, Kluwer Academic Publishers, 117〜178 (1996)

（8）山崎慶太：「磁気シールドルームの開発動向」, 電気 学会マグネティックス研究会資料，MAG-99-7 (1999)

（9）山崎慶太・阿部隆之・海野健一：「生体磁気棓湘用 磁気シールドルーム及びガントレの開発」, 日本建 築学会技術報告集，1，215２22（1996）

（10）概田裕：環境振動工学入門, 理工図書

（11）山原浩：環境保全のための防振設計，彰国社

(12) V.O.Kelh ä: "Construction and Performance of the Otaniemi Magnetically Shielded Room", IC SQUID / 3rd Workshop on Biomagnetism, Berlin, West Germany, March 6 9 (1980)

(13) A.Mager: "The Berlin Magnetically Shielded Room", Biomagnetism, $51 \sim 78(1981)$

(14) S.N.Erne, H.D. Halbohm, H. Scheer and Z.Trontelj: "The Berlin Magnetically Shielded Room (BMSR), Section B: Performances", Biomagnetism (1981)

(15) A.Mager: "Magnetisch abgeschirmte Kabine zur Aufnahme Kleinster magnetischer und electrisher Biosignale", Naturwissenschaften 69, $383 \sim 388$ (1982)

(16) Y.P.Ma and J.P.Wikswo, Jr.: "Magnetic Shield for Wide-Bandth Magnetic Measurements for Nondestructive Testing and Biomagnetism", Rev. Sci. Instrum., 62, 11, 2654〜2661（1991）

（17）高橋正広・佐々木勇三・古賀清 - 中村彰：「高性能 磁気シールドルームの試作」, 応用物理 52,1 , 59-68 (1983)

（18）田中基八郎・大久保信行：振動をみる，テクノライ フ選畫, オーム社

（19）阿部隆之 - 山崎慶太 - 藤原耕二・中瀨知哉：「磁気 シールドルームにおける振動と磁気ノイズに関する 唡討」, 電気学会マグネティックス研究会資料, MAG-97-224 (1997)

（20）阿部隆之・山崎慶太・藤原耕二 - 中瀬知哉：「環境 振動に起因する磁気シールドルームの磁気ノイス」, 第13回日本生体磁気学会大会論文集, 11，1，180 $\sim 181$ (1998) 
（21）TOKINカタログ：「磁気シールドルーム/装置」， Cat. No. OT-02JE July 00, 1998 H300P2

（22）NKK PLANTカタログ：「磁気シールドルーム」, NSS. '95.10-(2)-1 NSS

(23) D.S. Buchanan and R.T. Johnson: "Recent Develop -ments in Whole Head and Whole Body Magnetic Meas urements," 第13回日本生体磁気学会大会論文集, $11,1,44 \sim 48$ (1998)

(24) Ahonen, A. I. : "New developments in MEGinstruments," 第13回日本生体磁気学会大会論文集, 11 , 1, 50 53 (1998)

(25) J. Vrba: "Optimization of SQUID Detectors for MEG Application," 第13回日本生体磁気学会大会論文集, 11，1，54〜57 (1998)

（26）阿部隆之 - 山崎慶太 - 藤原耕二 - 中瀬知哉 : 「環境 振動に起因する磁気シールドルームの磁気ノイズ解 析」, 平10電気学会全国大会, No.512 (1998)

（27）阿部隆之・山崎慶太・藤巻則夫 ·宮内哲 : 「アクティ ブ除振装置を用いた磁気ノイズ低減」，第22回日本 応用磁気学会学術講演集, $21 \mathrm{aF}-6$ (1998)

(28) T. Abe, K Yamazaki, N. Fujimaki and S.Miyauchi : "Magnetic Noise Due to Environmental Vibration in Magnetically Shielded Room," to be published in Biomagnetism 98.

（29）阿部隆之 - 山崎慶太 · 佐久間学 - 原川健一 - 東山一 勇気・上野照剛・伊良皆啓治・三原利通；「生体磁 気計測用磁気シールドルームの研究 (その 3 ) 一環 境振動の影響評価一」, 日本建築学会大会学術講演 梗概集，1705 1706(1992)

（30）倉部誠・市原千治：「振動モード解析入門」, 日刊 工業新聞社

阿部隆之（正員） 1957 年 10 月 5 日生。 80 年

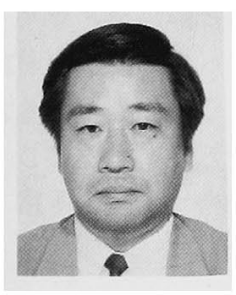
3 月東京理科大学理学部応用物理学科 卒業。同年 4 月（株）竹中工務店入社、 現在に至る。主として、環境振動の特 性および制御に関する研究、固体伝搬 音の予測技術に関する研究、環境振動 に起因する磁気ノイズに関する研究に 従事。日本建築学会、電気学会、日本 応用磁気学会、日本生体磁気学会
山崎 慶太 (正員) 1957 年 4 月 24 日生。 82 年

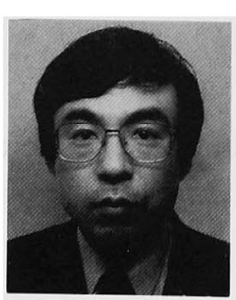

3 月早稲田大学大学院理工学研究科建 設工学専攻修士課程修了。同年 4 月 （株）竹中工務店入社、現在に至る。 主として、建築物に対する磁場の影響 とその評価法、および磁気応用技術に 関する研究に従事。日本生体磁気学会、 日本ME学会、日本応用磁気学会、日 本機械学会、日本建築学会会貝。博士 (工学)。

藤巻 則夫 （非会員） 1957 年 2 月 15 日生。 80 年

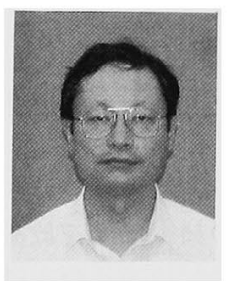
3 月東京大学大学院工学系研究科博士 課程修了。同年 4 月 (株) 富士通研究 所に入社、99 年 4 月郵政省通信総合 研究所にはいる。主として、超伝導デ バイス（マイクロ波・ミリ波検出器、 論理素子、磁気センサーなど）の研究、 EEG、MEG、fMRIによる脳機能計測の 研究に従事。電子情報通信学会、IEEE、 応用物理学会、日本生体磁気学会、日本 ME 学会、日本生理 心理学会、Society for Neuroscience。博士（工学）。

宮内 哲 (非会員) 1954 年9月 24 日生。7 7 年 3 月早稲田大学第一文学部心理学科卒 業。9 1 年 1 月岡崎国立共同研究機構 生理学研究所助手、93 年 10 月郵政 省通信総合研究所主任研究官、現在に 至る。主として、脳波・脳磁図・fMRI 心理実験による人の脳活動の非侵襲的 計測に関する研究に従事。日本神経科 学会、日本心理学会、日本生理心理学 会、日本生体磁気学会、日本睡眠学会 会貝。博士（医学）。

小林 宏一郎 (正員) 1968 年 4 月 3 日生。9 4 年

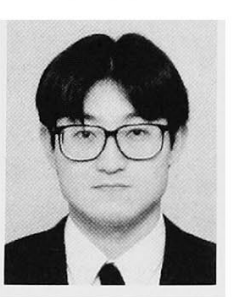

3 月東京電機大学理工学研究科応用電 子工学専攻修士課程修了。同年 4 月池 上通信機（株）入社、95 年 4 月東京 電機大学理工学部応用電子工学科助手、 98 年 10 月東京電機大学超電導応用 研究所助手、現在に至る。主として、 医用電子計測および信号処理に関する 研究に従事。日本生体磁気学会、日本 ME学会、日本応用磁気学会、ライフサポート学会会員。博 土 (工学)。 